\title{
MeANing From ChaOs: RefLections on SePtember 11, 2001 - TWO Years AfTer
}

\author{
Wayne N. Renke
}

\section{INTRODUCTION}

On 10 September 2002, the Centre for Constitutional Studies sponsored a symposium at the University of Alberta Faculty of Law, entitled "September 11, One Year Later." At the end of symposium, audience members put questions to the panel, on which I had the privilege of participating. The very last question was along these lines: "Would you say that anything good has come out of the events of September 11?" I shall attempt here to respond once more to that question. But I must take care with my response.

I must avoid the bad theology of finding purpose in every tragedy. Finding a message or lesson in disaster may be a mode of denial. It may be a way of making tolerable what is fundamentally intolerable; a way of making comprehensible what is fundamentally incomprehensible; a way of distracting us from what fundamentally demands to be seen. One might recall Job's quest to find the purpose of his tragedies, and his friends' poor efforts to establish that purpose: Job was ultimately answered by the Lord "out of the whirlwind"; and the Lord provided no justification or explanation, no description of hidden meaning. ${ }^{1}$ Calamities are not always parables.

These thoughts raise the issue of whether I should "say" anything about September 11. When faced with a horrifying event, we should resist our urge to hide it behind a cloud of words. Our primary posture before horror fixed in history should be one of silence. This allows the event to remain what it is and allows us to experience what it is as purely as we are able. We

The New Oxford Annotated Bible, rev. standard ed. (New York: Oxford University Press, 1973) "Job," c. 28-42 at 650-54. should have the courage to confront history without words. ${ }^{2}$

This is a caution not to resort to talk too quickly. But while meditation and due regard for experience should be a starting point, silence cannot be our only response to the world. On a general level, we are bound to try to move beyond experience and to make some sense of what has happened, to gain some understanding of events, to integrate events into our relevant intellectual frameworks. Our efforts at understanding and integration will entail verbalization, since we appropriate the world through our linguistic and conceptual apparatus. On a more practical level, September 11 demands not only silence and thought, but action. Unlike the case of Job, our story does not simply end with fortunes restored. We must work to repair, defend, and maintain. Our work is made easier by sound analysis.

But the movement to words engages another caution. Once the immediate need for action has been addressed, once we have the luxury of some time and distance - as we do now - we should not be embarrassed to engage in reflection that does not, or does not directly, serve practicality. Our path to assimilating a serious and terrible event should allow

\footnotetext{
One particular form of verbal thoughtlessness is turning away from the attacks to dwell on U.S. corporate blame - "but they deserved it"; "but U.S. foreign policy has resulted in many more casualties"; "but look at what happens every week in the Middle East"; or even "but this was the result of our secularism, pornography, and undermining of traditional institutions" (on the last, see C. Hitchens, A Long Short War: The Postponed Liberation of Iraq (Toronto: Penguin Canada, 2003) at 28. The "but" in this type of non-thought is a cowardly pivot that directs the gaze from these dead innocents to topics more comfortable to the speaker. I do not assert that U.S. - or Canadian foreign policy is immaculate. Our job as participants in our political processes is to criticize and reform. This job, however, must sometimes wait. Assessing grievous events in them selves and for themselves is a prior obligation. Glib distractive social criticism is only a form of bad faith in our relationship with the world and others.
} 
some place for relatively abstract, theoretical, "useless" reflection, that tries to stay close to the experience of the event itself. This is what I shall offer here, as a sort of meditative response to the audience's last question. ${ }^{3}$

In keeping with the context and location of our symposium, I shall try to relate September 11 to the law. Despite the terms of the question, with one exception, I shall not claim that any of the implications of September 11 which I describe were "good." The events happened. They may or may not have the significance I attribute to them. Their significance does not elevate innocent death to good.

\section{I}

The terrorist attacks of September 11 threw our constitutional system into stark relief. By "constitutional system," I mean our system of democratic politics that engenders and is bounded by statute and common law, and which is limited by our constitutional rules and the principles and values expressed in those rules. In the manner that being emerges only in contrast to nothingness, our constitutional system was set off or manifested against the negation of the attacks. The attacks represented an almost pure repudiation of the values supported by our constitutional system. The negation of the attacks sounded on four main levels.

First, our constitutional system, as developed particularly through our Charter ${ }^{4}$ jurisprudence, turns on the pre-eminent importance or moral primacy of the individual - on the dignity and autonomy of the natural person. ${ }^{5}$ Practically, the attacks repudiated the moral value of individuals; symbolically, the attacks preyed on our valuation of individuals. Practically: In the attacks, victims were used merely as means to ends. Individuals and their interests were not treated as

There is a psychological and psychiatric literature respecting responses to disaster: see C.A. Markstrom \& P.H. Charley, "Psychological effects of human caused environmental disasters: A case study of the Navajo and uranium" 2003 American Indian and Alaska Native Mental Health Research: The Journal of the National Center [forthcoming]. In contrast, I am gesturing towards a phenomenology of disaster - which I hope is not merely symptomatic.

4 Canadian Charter of Rights and Freedoms, Part I of the Constitution Act, 1982, being Schedule B to the Canada Act 1982 (U.K.), 1982, c. 11.

5 See $e . g$. the "presumption of innocence" jurisprudence: $R \cdot v$. Oakes, [1986] 1 S.C.R. 103 at 119-20 (Dickson C.J.C.); the "minimum fault" jurisprudence: e.g. Re B.C. Motor Vehicles Act, [1985] 2 S.C.R. 486 at 503 (Lamer J.); and R. v. Martineau, [1990] 2 S.C.R. 633 at 645-46 (Lamer C.J.C.); the "privacy" jurisprudence: e.g.R.v.Dyment, [1988] 2 S.C.R. 417 at 427, 429 (La Forest J.); and the freedom of expression jurisprudence: e.g. Irwin Toy Ltd. v. Quebec (A.G.), [1989] 1 S.C.R. 927 at 976 (Dickson C.J.C., Lamer and Wilson JJ.). warranting any special protection, but were subordinated to the interests of the terrorists. The victims were killed to make the terrorists' point, whatever that might have been. Indeed, the terrorists' contempt for life extended to their own lives - they gave up their own lives willingly. Symbolically: The outrage we felt at the attacks was, in part, in response to individuals being treated merely as means, as nothing more than things used by the terrorists for their purposes. Moreover, these were innocent individuals, who had not consented to be put in harm's way, and who in no way deserved to die. Absent consent or desert, our belief would be that the victims should have been left alone.

Second, our constitutional system is based on the "rule of law," a commitment manifest in the Preamble to the Charter. One aspect of the rule of law is the principle that public acts be rationally defensible. ${ }^{6}$ This rational defensibility principle presupposes an "existential" setting. Rational defensibility is possible only in an environment in which individuals and their opinions matter deeply (again the importance of the individual); opinions are judged against objective or interpersonally accepted standards; emotion or passion, important as they may be, are subordinated to rationality; debate is conducted according to more-orless explicit procedural rules; and action is deferred until decisions are duly reached. The attacks repudiated rational debate and its setting. The attacks were the subject of thought (malice aforethought), but conveyed no rational meaning. The attacks were not debate, but a silencing. The attacks exhibited passion, without the bridle of reason. The attacks demonstrated action, not human-to-human communication. ${ }^{7}$

Third, our constitutional system is secular, while it permits individuals freedom of religion. The Preamble to the Charter does state that "Canada is founded upon principles that recognize the supremacy of God and the rule of law." It is worth noting that the term "and" links "the supremacy of God" to "the rule of law." We do not put the deity (anyone's deity) above the law. The deity and the rule of law are coordinated. A natural law theorist may approve of the link between the deity and our basic law; a theorist bearing Occam's razor may consider the coordinated deity to add nothing to the basic law itself. Regardless, the deistic reference in the Preamble has not permitted the promotion of religious

6 Reference re Remuneration of Judges of the Provincial Court of Prince Edward Island, [1997] 3 S.C.R. 3 at para. 181 (Lamer C.J.C.).

7 "Enfolded in any definition of 'terrorism' ... there should be a clear finding of fundamental irrationality": Hitchens, supra note 2 at 25. 
ends (as by legislation) at the expense of Charter rights and freedoms. ${ }^{8}$ Insofar as the attacks had a religious motivation, they put the deity and service to the deity precisely above the law. The pursuit of perceived religious interests overwhelmed all rules for civilized human community.

Fourth, our constitutional system, as a species of democracy, presupposes a substantial public commitment to mutual trust. If we are to accede to the views of a majority that does not include us, we must have some assurance that others will not discriminate against us merely because of our minority status. ${ }^{9} \mathrm{We}$ need not be convinced of the majority's wisdom, so long as we are assured of its good will. Even more fundamentally, our day-to-day transactions and interactions are premised on the silent assumption that others will not intentionally injure us or subject us to excessive risk. We know that we do face some risks from others, but, for the most part, our trust in others is borne out. The attacks both exploited and repudiated our trust. The attacks were facilitated by our trust, by our assumption that no one, particularly people who had lived among us, would attempt actions like the attacks. The attacks raised the possibility that our trust of others is misplaced. If the attacks were carried out once, they may be carried out again. If they were carried out by others' neighbours before, they may be carried out by our neighbours next time.

By throwing our constitutional system into relief, the attacks of September 11 did not thereby justify our system. The attacks only made more apparent what our system is.

The contrast between our system and the attacks creates a space for choice. The terrorists' tactics may have a certain allure: as they did to us, so we should do to them (if we can find a suitable "them"). At the very least, we might consider abandoning some elements of our system, in an effort to reduce the risks of further attacks. We might wonder whether we should maintain our commitment to our constitutional system, in the face of the radical challenge of the attacks.

8 R.v.Big M Drug Mart, [1985] 1 S.C.R. 295 (Dickson C.J.C.) In particular contexts, freedom of religion may have to be balanced against other Charter rights, such as the right to be free from discrimination, protected under s. 15: Trinity Western University v. British Columbia College of Teachers, [2001] 1 S.C.R. 772

9 Of course, mutual trust has had to expand outward from the trust extended to members of one's own ethnic and social groups, and the expansion has not been perfect. We are not done with Human Rights Commissions or s. 15 litigation.
This line of speculation is misplaced. Assume that we do believe that our constitutional system and the values it embodies are right. The principles and values that lay claim to us, then, are what we should pursue, promote, and maintain. That is what it means to say that the principles and values are "right." To ask why we "should" do what we know we "should" do is, if not nonsensical, at least odd. Furthermore, the moral obligation to do the right thing does not depend on whether doing the right thing would be hard or easy. A moral obligation is significant just because it directs us to act against our non-moral inclinations. Maintaining constitutional principles in times of peace and relative domestic calm takes no great resolve. Commitment only in good times is not commitment at all. If we do truly believe in the value of individuals and the rule of law, that must entail that we will abide by our principles, despite provocation. It is true that "ought implies can" and principles are not to be a death sentence. If we cannot realistically adhere to our principles fully because of the pressure of circumstance, we may be excused. We have the responsibility of deciding whether circumstance has overcome us, or whether we may overcome circumstance. September 11 tests our will to preserve the right, the depth of our commitment:

To paraphrase what La Rochefoucauld once remarked with regard to love, one might say that just as the small fire is extinguished by the storm whereas a large fire is enhanced by it - likewise a weak faith is weakened by predicaments and catastrophes whereas a strong faith is strengthened by them. ${ }^{10}$

\section{II}

September 11 exposed our personal vulnerability. Part of the explanation for the strong impact of the attacks is our recognition that we could have been the people in the airplanes or in the buildings - or if not us, our friends or our relatives. Vulnerability is indiscriminate. Terrorists do not care about your voting patterns, your support for international peace, your strong arguments in favour of tolerance and understanding. If you are caught in the wrong place, you are dead. Like it or not, we are all in the fight. ${ }^{11}$

10 V.E. Frank1, The Unconscious God: Psychotherapy and Theology (New York: Simon \& Schuster, 1975) at 16.

11 "The whole point of the present phase of conflict is that we are faced with tactics that are directed primarily at civilians.... It is amazing that this essential element of the crisis should have taken so long to sink into certain skulls": Hitchens, supra note 2 at 20. See also A.M. Dershowitz, Why Terrorism Works: Understanding the Threat, Responding to the Challenge (New Haven: Yale University Press, 2002) at 108. 
Of course, we all were vulnerable before September 11. Ask any victim of violent crime. September 11, however, did vaporize the complacency or obliviousness we might have absorbed from our geography and history. We felt safe here, at least from the violence of the Middle East. ${ }^{12}$

The reminder of vulnerability pushes in two directions. First, it encourages personal responsibility. The attacks, particularly involving American Airlines Flight 93, reminded us (should we have needed reminding) that public security personnel will not always be present to assist us when circumstances go bad. A feature of living on the new front lines is that we must be prepared to take action ourselves, if the situation demands it. If we know that we may have to take responsibility for our own safety and the safety of our family and friends, we must be alert. We cannot stay constantly in "condition white," ignoring what's around us - leaving our security to others..$^{13}$ Taking personal responsibility entails a proper balancing of the relationship between civilians and public security agencies. On the one hand, we should ensure that we do not give up too much psychological or legal power to the state. On the other hand, we should not think that we can replace security professionals. Our competence is only limited and transitory.

At this point, we begin to march on a delicate constitutional edge. In aid of the "proper balancing," one might be inclined to favour greater co-operation between civilians and public security agencies. "Tipster" programs may be proposed, permitting civilians to provide information to investigatory agencies. ${ }^{14}$ We already have Crime Stoppers programs, and have strong evidential protections for informers. ${ }^{15}$ But we do not want to become a society of informers. ${ }^{16}$

12 Certainly another factor amplifying the psychological impact of the attacks was the violation of our territorial integrity: see $\mathrm{N}$. Chomsky, 9-11 (New York: Seven Stories Press, 2001) at 12. While the factual and moral scope of tragedies at different locations may be precisely equivalent, in terms of our perceptions, it is one thing for horrible events to happen there; it is quite another for them to happen here.

13 The four-part awareness colour code was devised by Jeff Cooper. It is widely used in law enforcement and private defensive training. The other levels are "condition yellow" a state of relaxed alertness, "condition orange" - a state of alarm, and "condition red" - combat consciousness: see E. Lovette \& D. Spaulding, Defensive Living (Flushing: Looseleaf Law Publications, 2000) at 18.

14 “Operation TIPS Fact Sheet," online: <www.citizencorps.gov/tips.html>; D. Kash, "Hunting Terrorists Using Confidential Inform ant Reward Programs" FBI Law Enforcement Bulletin (April 2002), 26.

15 R. v. Leipert, [1997] 1 S.C.R. 281 (McLachlin J.).

16 When Germany unified, it was learned that the Stasi, the East German intelligence agency, had collected information about many citizens willingly supplied by other citizens: "The Stasi
(We might consider that the targets of suspicion are likely to belong to visible minorities.) Similarly, increased public video surveillance might be advocated.$^{17}$ But we do not want to become a Panoptic society, under the relentless eye of the state. Overemphasizing co-operation with authorities could undermine the mutual trust on which our constitutional system relies, and could undermine our constitutionally-protected rights.

What tends to imbalance sensible relations between citizens and public authorities is the second "push" of vulnerability. Vulnerability engenders fear. We should not underestimate the constitutive political role of fear. Plato, for example, tells us that the tyrant is motivated chiefly by fear:

\begin{abstract}
Therefore, the real tyrant is, even if he doesn't seem so to someone, in truth a real slave to the greatest fawning and slavery, and a flatterer of the most worthless men; and with his desires getting no kind of satisfaction, he shows that he is most in need of the most things and poor in truth, if one knows how to look at a soul as a whole. Throughout his entire life he is full of fear, overflowing with convulsions and pains. ${ }^{18}$
\end{abstract}

Hobbes lay his conception of the social contract on a foundation of fear: In the state of nature, "where every man is Enemy to every man," there is "continuall feare, and danger of violent death; And the life of man, solitary, poore, nasty, brutish, and short." 19 Fear is polymorphic. Fear could drive our leaders into the shell of Plato's tyranny. Fear could drive citizens toward an over-reliance on the state, toward the subordination of individual rights and freedoms to state interests. Fear could take us to Hobbes' authoritarian sovereign. In contrast, fear could drive us toward an overreliance on ourselves. If we become suspicious of others, if we lose the mutual trust on which our constitutional system is founded, if we do not believe that our majorities (or those with "real political power") will act in good faith,

built an astonishingly widespread network of informants researchers estimate that out of a population of 16 million, 400,000 people actively cooperated. The Stasi kept files on up to 6 million East German citizens - one-third of the entire population," online: CNN Interactive <edition.cnn.com/specials/cold.war/experience/ spies/spy.files/intelligence/stasi.htm >. See also J. Legner, "Commissioner for the Stasi Files" (2003) 28 German Issues, online: <www .aicgs.org/publications/PDF/legner.pdf>.

17 "In the past decade, successive UK governments have installed over 1.5 million cameras in response to terrorist bombings. While the average Londoner is estimated to have their picture recorded more than three hundred times a day, no single bomber has been caught," online: Electronic Privacy Information Center <www .epic.org/privacy/surveillance>

18 The Republic of Plato, trans. by A. Bloom (New York: Basic Books, 1968) at 260 .

19 T. Hobbes, Leviathan, ed. by C.B. MacPherson (New York: Penguin Books, 1968) c. 8 at 186. 
we might retreat to small isolated communities of individuals who share our beliefs and who alone can be trusted. Fear could take us to the militia movement and social fragmentation.

September 11 opened us to personal responsibility, and may serve as a catalyst for a new balance of personal and public security. We must take care that the fear that ripples from the attacks does not tilt this balance toward either excessive or inadequate State authority.

\section{III}

September 11 reminded us of a reality noted by Simone Weil - the good has no force. ${ }^{20}$ What I mean is this: We conduct ourselves according to a variety of rules and practices, including moral and legal rules. With respect to moral and legal rules, what forces, compels, or binds us to follow those rules? One might respond that multiple mechanisms ensure compliance. We have established processes and penalties to deter; social stigma attaching to prosecution or conviction may deter; we may be biologically "hard-wired" not to perform some criminal actions, such as assault or murder; ${ }^{21}$ we may be habituated, trained, or disciplined to abide by norms; we may be wholly or partially incapacitated (whether by incarceration or drugs) from offending. What, though, of potential offenders like the terrorists, who will not suffer social stigma if caught, who are unconcerned with potential penalties (who are in fact willing to die to carry out their plans), and who believe that their actions are justified by the ends they seek? For them, the good - our good - certainly has no force. And what of us? Unless we are incapacitated, what stops us now, even as bound by chains of deterrence, biology, or socialization, from committing offences? What blocks us from pursuing what we know is wrong? The answer, put baldly, is nothing. If we want to offend, we can offend. People choose to violate our moral and legal rules every day, often (although not always) because they believe they can "get away with it." Although we may know what is good and right, that knowledge does not force us to obey. In this sense, even for us, the good has no force.

The terrorists demonstrated the radical weakness of good; they demonstrated the triumph of will, of choice, over right. They showed just how easy it is to subvert, destroy, and violate. We should not forget that the

20 S. Weil, Gateway to God, ed. by D. Raper (Glasgow: Fontana Books, 1974) at 37 .

21 D. Grossman, On Killing: The Psychological Cost of Learning to Kill in War and Society (New York: Little, Brown, 1995) at 6. attacks were low-budget (their cost has been estimated at about $\$ 400,000$ ) and low-tech (box-cutters and flying lessons). Attacks of this nature are not beyond any determined person or group. Again, the attack's negation throws our reality into visibility. The marvel exposed is that our system, on the whole, to a greater or lesser degree, relies on individuals choosing to follow moral and legal rules. I do not ignore crime, cheating, depravity. I do not ignore that fact that some of our communities have become the moral equivalents of war zones. My point is only that, despite temptation and opportunity, we manage to work and live together with surprisingly little friction. What makes this marvelous or worthy of wonder is that our system is sustained by such a fragile thing as our choice. Our reality could easily - all too easily - be otherwise, as many other communities in many other places show.

The terrorists may have demonstrated the weakness of good, but they did not destroy good or the will to pursue it. Consider the actions of the firefighters who responded to the attacks. They ran into the smoke and fire. Carrying heavy equipment, they ran up flights of steps, through heat and panic and exhaustion. They ran to save the ordinary people caught in the destruction, and to save friends who had been trapped. They died to save others. Their sacrifice attested to the value of life. Their sacrifice marked their hard choice to do what was right. If it is possible to say that anything "good" came out of the attacks of September 11, it was their example - a light that the darkness of September 11 could not extinguish.

\section{Wayne N. Renke}

Professor, Faculty of Law, University of Alberta 